\title{
ANALISIS KESALAHAN SISWA DALAM MENYELESAIAKAN SOAL CERITA TENTANG PERBANDINGAN
}

\author{
${ }^{1)}$ Supriyanto, supriyanto@stitmatuban.ac.id
}

\begin{abstract}
This study aims to describe the location, type, and factors causing students to make mistakes in solving the story of the comparison. And to arrange alternative learning so that errors do not happen again. The determination of research subjects based on the results of the analysis of student work outcomes on the question of diagnostic tests provided. With diagnostic tests can be known location and type of student error, while to determine the factors causing the error obtained from an interviews with the subject of research. From the research, it is known that the research subjects made mistake in every step of problem-solving that is: understanding the problem, devising a plan, carrying out the plan, and looking back and make a conclusion. The types of mistakes made by the students are as follows: 1) the error of facts: incomplete in writing what is known about, 2) misconceptions: not making the right plan, wrong in determining the percentage of a value, wrong in comparing, Determining the values compared, wrong in determining the type of comparison, 3) principle error: incorrect in using formulas to determine percentages, and incorrect in determining unknown values in comparison, and 4) operation errors: errors in simplifying fractions. Factors that cause errors are a lack of thorough students in reading and understanding problems, difficulties in using and analyzing information on the problem, the existence of a misconception about the comparison. Based on the characteristics of factors causing mistakes made by students, then Problem Based Learning is one effective way to embed the concept of comparison and familiarize students in solving math problems.
\end{abstract}

Key words: error analysis, word problem, ratio

\section{Pendahuluan}

Matematika perlu dikuasai oleh segenap warga Indonesia, baik penerapannya maupun pola pikirnya sampai batas tertentu. ${ }^{1}$ Oleh karena itu pemerintah melalui Kemendikbud menerapkan Kurikulum 2013 dengan harapan pembelajaran matematika ditingkat sekolah menengah mampu mendorong siswa untuk mencari tahu dari berbagai sumber, mampu merumuskan masalah bukan hanya menyelesaikan masalah sederhana dalam kehidupan seharihari. hal ini menyiratkan bahwa pengembangan kemampuan masalah merupakan fokus tujuan utama pembelajaran matematika. ${ }^{2}$

\footnotetext{
${ }^{1}$ R Soedjadi, Kiat Pendidikan Matematika di Indonesia. Jakarta: Direktorat Jenderal Pendidikan Tinggi Departemen Pendidikan Nasional, 2000.

${ }^{2}$ NCTM, Principles and Standars for School Mathematics. United State: NCTM, Inc, 2000.
} 
Bentuk soal untuk mengukur kemampuan siswa dapat berupa soal cerita maupun soal non cerita. Kemampuan siswa dalam menyelesaikan soal cerita akan berpengaruh terhadap prestasi belajarnya. Hal ini dikarenakan selalu terdapat soal-soal cerita dalam tes-tes yang dijalani oleh siswa. Soal cerita mempunyai peranan penting karena siswa akan mengetahui hakekat suatu permasalahan matematika. Dalam menyelesaikan soal cerita siswa dituntut untuk melakukan proses berfikir yang lebih kompleks dalam menentukan langkah-langkah yang akan ditempuh. ${ }^{3}$

Banyaknya kesalahan yang dilakukan siswa dalam memecahkan soal matematika dapat menjadi salah satu petunjuk sejauh mana penguasaan siswa terhadap materi yang dipelajari. Dari kesalahan yang dilakukan siswa dapat diketahui lebih lanjut secara mendalam mengenai sumber kesalahannya. Sumber kesalahan ini penting untuk diketahui dan segera memperoleh pemecahan/solusi secara tuntas agar hasil pembelajaran matematika di kelas menjadi maksimal.

Salah satu permasalahan yang siswa sering melakukan kesalahan dalam menyelesaikannya adalah permasalahan yang berkaitan dengan perbandingan. Seorang siswa dapat memiliki kepekaan yang kuat terhadap ukuran dan sifat dari kuantitas-kuantitas, seperti kecepatan, dan dapat menggunakan kosakata yang sesuai (misal, mil per jam) dengan tepat tanpa menyadari hubungan antar bilangan yang menyusun perbandingan tersebut. ${ }^{4}$ Ia melakukan kesalahan dalam menyelesaikan permasalahan perbandingan dengan mengabaikan hubungan antar kuantitas yang menyusun perbandingan tersebut. Padahal pemahaman tentang itu mutlak diperlukan.

\section{Kajian Teori}

Objek dasar yang dipelajari dalam matematika adalah abstrak, sering juga disebut sebagai objek mental. Objek dasar itu meliputi fakta, konsep, prinsip, dan operasi. ${ }^{5}$ Fakta matematika adalah konvensi atau kesepakatan dalam matematika yang disajikan dalam bentuk kata-kata maupun simbol-simbol atau gambar tertentu. Ide-ide abstrak yang dibentuk dari fakta dan dapat digunakan untuk menggolongkan sekumpulan objek merupakan konsep matematika. Operasi

\footnotetext{
${ }^{3}$ Yaya S Kusumah, "Literasi Matematis: Pengembangan Pembelajaran MIPA berrientasi Softskill," in Seminar Nasional Pendidikan MIPA, Lampung, 2011, p. 6.

${ }^{4}$ S J Lamon, "Ratio and Proportion: Coneccting Content and Children's Thinking," Journal for Research in Mathematics Educations Vol. 24 No.1 (January), pp. 41-61, 1993.

${ }^{5}$ R Soedjadi, Kiat Pendidikan Matematika di Indonesia. Jakarta: Direktorat Jenderal Pendidikan Tinggi Departemen Pendidikan Nasional, 2000.
} 
adalah pengerjaan hitung, pengerjaan aljabar, dan pengerjaan matematika yang lain ${ }^{6}$, sedangkan prinsip adalah hubungan antara dua atau lebih objek-objek matematika. objek-objek matematika yang dihubungkan dapat terdiri dari beberapa fakta, beberapa konsep yang dihubungkan dengan suatu relasi atau operasi.

Ducker mengatakan bahwa masalah akan muncul ketika seseorang mempunyai tujuan khusus tetapi dia tidak mengetahui bagaimana untuk menyelesaikannya. Masalah dapat diartikan sebagai situasi atau pertanyaan yang dihadapi seseorang individu atau kelompok ketika mereka tidak mempunyai aturan, algoritma/prosedur tertentu atau hukum yang segera dapat digunakan untuk menemukan jawabannya ${ }^{7}$. Masalah adalah situasi, kuantitatif atau yang lainnya, yang menghadapkan individu atau kelompok individu, yang memerlukan penyelesian, dan untuk itu individu tidak melihat jalan langsung untuk mendapatkan penyelesaian ${ }^{8}$.

Dari paparan tersebut dapat disimpulkan bahwa masalah dalam matematika adalah pertanyaan matematika dimana siswa tidak dapat memecahkan dengan aturan atau hukum yang sudah diketahuinya untuk menjawab pertanyaan tersebut dan siswa tersebut mempunyai niat (adanya suatu tantangan) untuk menyelesaikannya.

Pemecahan masalah merupakan usaha untuk mencari jalan keluar dari suatu kesulitan, mencapai suatu tujuan yang tidak dengan segera dapat dicapai. Karena itu pemecahan masalah merupakan suatu tingkat aktivitas intelektual yang tinggi [ HYPERLINK 1 "Pol73" 7 ]. ${ }^{9}$ Terdapat empat langkah pemecahan masalah yang disampaikan oleh Polya, yaitu memahami masalah, merencanakan penyelesaian, menyelesaikan masalah sesuai dengan rencana, memeriksa kembali dan mendiskusikan jawaban yang diperoleh.

Berikut uraian tentang langkah-langkah pemecahan masalah Polya: 1) Memahami masalah (Understanding the Problem). Tanpa adanya pemahaman terhadap masalah yang diberikan, siswa tidak mungkin mampu menyelesaikan soal (masalah) yang diberikan dengan benar. Langkah ini dimulai dengan pengenalan apa yang tidak diketahui atau apa yang ingin didapatkan. Selanjutnya oemahaman apa yang diketahui serta data apa yang tersedia, kemudian

\footnotetext{
${ }^{6}$ R Soedjadi, Kiat Pendidikan Matematika di Indonesia. Jakarta: Direktorat Jenderal Pendidikan Tinggi Departemen Pendidikan Nasional, 2000.

${ }^{7}$ Tatag Yuli Eko Siswono, Model Pembelajaran Matematika Berbasis Pengajuan dan Pemencahan Masalah untuk Meningkatkan Kemampuan Berpikir Kreatif. Surabaya: Unesa University Press, 2008.

${ }^{8}$ Stephen Krulik and Jesse A Rudnick, The New Sourcebook for Teaching Reasoning and Problem Solving in Elementary School. Boston: Allyn and Bacon, 1995.

${ }^{9}$ S Sahriah, M Muksar, and T E Lestari. (2012) Jurnal Online. [Online]. http://jurnalonline.um.ac.id/data/artikel/artikel19EEC8FEB3F87AC825C375098E45CB689.pdf
} 
melihat apakah data serta kondisi yang tersedia mencukupi untuk menentukan apa yang ingin didapatkan. 2) Merencanakan penyelesaian (Devising a plan). Dalam menyusun rencana pemecahan masalah diperlukan kemampuan untuk melihat hubungan antara data serta kondisi apa yang tersedia dengan data apa yang tidak dikatahui/dicari. Selanjutnya menyusun sebuah rencana pemecahan masalah dengan memperhatikan atau mengingat kembali pengalaman sebelumnya tentang masalah-masalah yang berhubungan. Pada langkah ini siswa diharapkan dapat membuat suatu model matematika untuk selanjutnya dapat diselesaikan dengan menggunakan aturan-aturan matematika yang ada. 3) Menyelesaikan masalah sesuai rencana (Carrying Out The Plan). Rencana penyelesaian yang telah dibuat sebelumnya, kemudian dilaksanakan secara cermat setiap langkah. Dalam melaksanakan rencana atau menyelesaikan model matematika yang telah dibuat pada langkah sebelumnya, siswa diharapkan memperhatikan prinsip-prinsip/aturan-aturan pengerjaan yang ada untuk mendapatkan hasil penyelesaian model yang benar. Kesalahan jawaban model dapat mengakibatkan kesalahan dalam menjawab permasalahan soal. Untuk itu, pengecekan pada setiap langkah penyelesaian harus selalu dilakukan untuk memastikan kebenaran jawaban model tersebut. 4) Memeriksa kembali (Looking Back). Hasil penyelesaian yang didapat harus diperiksa kembali untuk memastikan apakah penyelesaian tersebut sesuai dengan yang diinginkan dalam soal (masalah) atau tidak. Apabila hasil yang didapat tidak sesuai dengan yang diminta, maka perlu pemeriksaan kembali atas setiap langkah yang telah dilakukan untuk mendapatkan hasil sesuai dengan masalahnya, dan melihat kemungkinan lain yang dapat dilakukan untuk menyelesaikan soal (masalah) tersebut. Dari pemeriksaan tersebut maka berbagai kesalahan yang tidak perlu dapat terkoreksi kembali sehingga siswa dapat sampai pada jawaban yang benar sesuai dengan soal (masalah) yang diberikan.

Kesalahan siswa dalam menyelesaikan soal cerita dalam penelitian ini adalah kekeliruan yang dilakukan oleh siswa dalam menyelesaikan sola cerita tentang perbandingan. Jika diperhatikan kesalahan siswa dalam menyelesaikan soal matematika sangatlah bervariasi. Kesalahan yang dibahas dalam penelitian ini ditinjau dari letak kesalahan dan jenis kesalahan.

Letak kesalahan adalah tempat beradanya kesalahan siswa pada langkah-langkah menyelesaikan soal cerita. Dalam penelitian ini letak kesalahan yang dikaji didasarkan atas hasil pemeriksaan jawaban pada lembar tes siswa dalam memecahkan soal cerita tentang perbandingan, yang meliputi kesalahan dalam memahami soal, membuat rencana penyelesaian, 
melaksanakan rencana penyelesaian, dan memeriksa kembali jawaban yang diperoleh. Dengan demikian siswa dikatakan membuat kesalahan apabila ia mengerjakan soal dengan tidak benar. Hal ini bisa terjadi pada proses memahami soal, penyelesaian soal maupun pada hasil akhir.

Kesalahan merupakan bentuk penyimpangan terhadap hal yang benar, prosedur yang ditetapkan sebelumnya, atau penyimpangan dari suatu yang diharapkan. Langkah-langkah pemecahan masalah matematika yang berbentuk uraian, siswa melakukan kegiatan intelektual yang dituangkan pada kertas pekerjaan, dari kertas ini dapat dilihat jenis kesalahan yang dilakukan siswa. ${ }^{10}$

Kesalahan siswa dalam menyelesaikan soal cerita adalah kesalahan konsep, kesalahan operasi dan kesalahan ceroboh, dengan kesalahan yang dominan adalah kesalahan konsep. Jenis kesalahan yang dikaji dalam penelitian ini adalah kesalahan fakta, kesalahan konsep, kesalahan prinsip, dan kesalahan operasi. ${ }^{11}$

Faktor utama yang mempengarui kesulitan belajar pada siswa adalah berasal dari dalam diri anak sendiri (internal). Untuk mengetahui faktor penyebab kesalahan yang ditimbulkan secara eksternal diperlukan waktu yang lebih lama dan indikator yang kompleks. Oleh karena itu dalam penelitian ini penyebab kesalahan dibatasi hanya pada penyebab yang berasal dari diri siswa yang menyangkut kognitif siswa (faktor internal siswa) yaitu kemampuan intelektual siswa dalam memecahkan soal cerita tentang perbandingan.

Adapun faktor penyebab kesalahan yang disebabkan oleh faktor kognitif dalam penelitian ini meliputi kesalahan fakta, kesalahan konsep, kesalahan prinsip, dan kesalahan operasi. Kesulitan siswa dalam mempelajari prinsip dapat disebabkan oleh belum dipahaminya sebagian atau seluruh pengetahuan prasyarat yang diperlukan. Mungkin siswa menggunakan pemahaman yang keliru tentang konsep yang merupakan prasyarat dari prinsip tersebut. Dalam penelitian ini, yang dimaksud dengan faktor penyebab kesalahan adalah hal-hal yang ikut mempengaruhi siswa melakukan kesalahan dalam menyelesaikan soal cerita. Faktor penyebab kesalahan siswa dapat diketahui melalui kegiatan wawancara.

\footnotetext{
${ }^{10}$ S Sahriah, M Muksar, and T E Lestari. (2012) Jurnal Online. [Online]. http://jurnalonline.um.ac.id/data/artikel/artikel19EEC8FEB3F87AC825C375098E45CB689.pdf

${ }^{11}$ Pratana Phonapichat, An Analysis of Elementary School Students Difficulties In Mathematical problem Solving. Bangkok: Chulalongkorn University, 2013.
} 


\section{Metode}

Penelitian diawali dengan menyusun soal tes diagnostik untuk mengetahui letak dan jenis kesalahan siswa. Sebelum diujikan, dilakukan validasi soal tes diagnostik yang meliputi kesesuaian materi dengan tujuan penelitian (isi), konstruksi soal, dan kesesuaian bahasa yang digunakan. Kemudian dilanjutkan dengan merevisi soal tes diagnostik sesuai dengan masukan dari validator. Setelah tes dilaksanakan, selanjutnya dilakukan analisis kesalahan pada setiap langkah penyelesaian soal. Kegiatan ini dilakukan dengan memeriksa jawaban siswa untuk mengetahui letak dan jenis kesalahan. Untuk mengetahui keabsahan data dilakukan triangulasi, yaitu dengan membandingkan data yang diperoleh dari lembar jawaban dan wawancara. Sedangkan untuk mengetahui faktor penyebab terjadinya kesalahan dilakukan melalui wawancara terhadap siswa. Untuk mempermudah proses analisis data, maka dilakukan pelabelan dan pengkodean pada transkrip wawancara.

\section{Hasil dan Pembahasan}

Dari kegiatan penelitian yang telah dilakukan, diperoleh data bahwa siswa melakukan kesalahan disetiap langkah penyelesaian masalah, yaitu pada tahap memahami masalah, membuat rencana penyelesaian, melaksanakan rencana penyelesaian, dan memeriksa kembali dan membuat kesimpulan.

Berdasarkan hasil tes dan wawancara dengan subjek penelitian diperoleh hasil sebagai berikut:

\section{Subjek penelitian 1 (SP-1)}

a. Soal nomor 1

Doni mempunyai 20 butir kelereng lebih banyak dari milik Andre, sedangkan kelereng Ridho jumlahnya setengah dari kelereng Doni. Jika Andre memiliki kelereng sebanyak $n$ butir dan jumlah kelereng mereka bertiga 55 butir. Berapakah persentase kelereng yang dimiliki Ridho dari keseluruhan kelereng mereka bertiga?

\section{Analisis kesalahan SP-1}

Hasil jawaban SP-1 sebagai berikut: 
1) Langkah memahami masalah

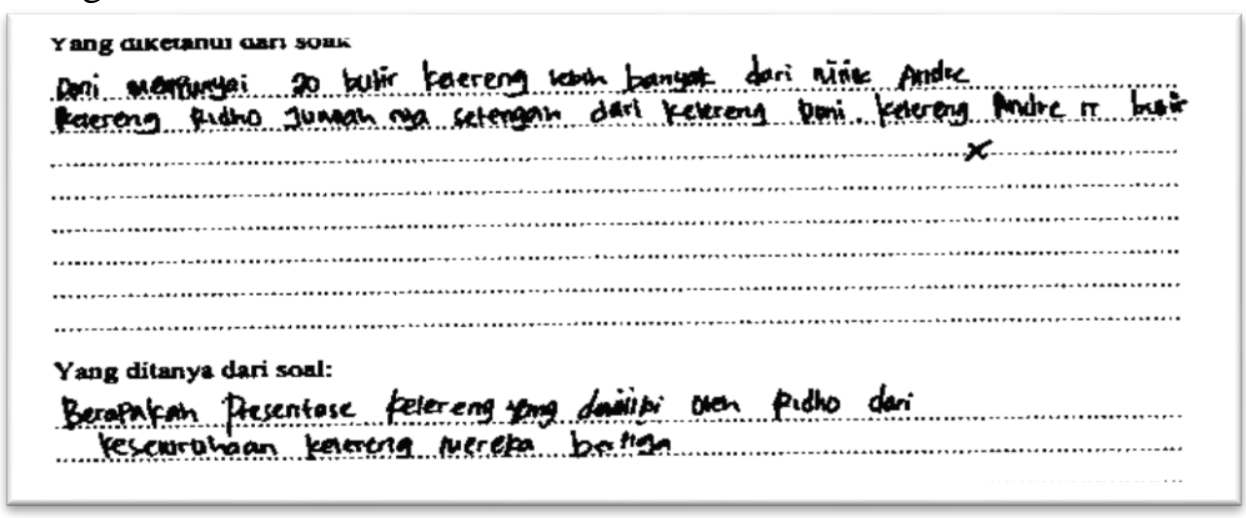

Gambar 1: Jawaban SP-1 pada Langkah Memahami Masalah

Dari jawaban tersebut, dapat diidentifikasi bahwa SP-1 telah melakukan kesalahan pada tahap memahami masalah. Jenis kesalahan yang dilaukan SP-1 adalah kesalahan fakta yakni tidak lengkap dalam menuliskan apa yang diketahui dalam soal. Dari wawancara dengan SP-1 diperoleh petikan sebagai berikut:

\begin{tabular}{|c|c|}
\hline P1.1.3 & $\begin{array}{l}\text { : Apakah kamu sudah membaca dan mamahami soal } \\
\text { nomor } 1 \text { ? }\end{array}$ \\
\hline SP-1.1.3 & : Sudah pak \\
\hline P1.1.4 & : Apa yang diketahui pada soal nomor 1 \\
\hline SP-1.1.4 & $\begin{array}{l}\text { Doni mempunyai } 20 \text { butir kelereng lebih banyak dari } \\
\text { milik Andre. Kelereng Ridho jumlahnya setengah } \\
\text { kelereng Doni. Kelereng Andre } \mathrm{n} \text { butir }\end{array}$ \\
\hline P1.1.5 & : Apakah hanya itu saja? \\
\hline SP-1.1.5 & : Iya pak \\
\hline P1.1.6 & Coba baca lagi \\
\hline SP-1.1.6 & Hmmmm (terus diam) \\
\hline P1.1.7 & Sudah dibaca lagi? \\
\hline SP-1.1.7 & Sudah pak \\
\hline P1.1.8 & Apakah sudah lengkap apa yang kamu sebutkan tadi? \\
\hline SP-1.1.8 & $\begin{array}{l}: \text { Ada yang kurang pak. } \\
\text { Jumlah kelereng mereka bertiga } 55 \text { butir }\end{array}$ \\
\hline P1.1.9 & Bagus. Kenapa kemarin tidak kamu tuliskan yang itu? \\
\hline SP-1.1.9 & $\begin{array}{l}\text { : Hmmmm.... } \\
\text { Tidak tahu }\end{array}$ \\
\hline P1.1.10 & Lho kok tidak tahu. Maksudnya gimana kok tidak tahu \\
\hline SP-1.1.10 & : Kurang teliti baca soalnya pak \\
\hline
\end{tabular}

Berdasarkan pada jawaban SP-1 pada tahap memahami masalah dan hasil wawancara dengan label jawaban SP-1.1.4 terdapat kesamaan kesalahan yang 
dilakukan, yaitu SP-1 melakukan kesalahan waktu. Ini menunjukkan adanya kekonsistenan jawaban yang diberikan oleh SP-1 sehingga data yang diperoleh pada tahap ini dikatakan valid.

Pada petikan wawancara dengan kode SP-1.1.10, dapat diketahui bahwa faktor penyebab terjadinya kesalahan adalah kekurangtelitian SP-1 dalam membaca soal.

2) Langkah merencanakan penyelesaian

Rencana penyelesaian:

Yaltu dengan Mengetahui beberapa butir kefereng. Presentase dan . Jumah -...esedurahan .....ereka bertiga.

$x$

Gambar 2: Jawaban siswa pada tahap merencanakan penyelesaian

Berdasarkan jawaban di atas, pada tahap merencanakan penyelesaian SP-1 hanya menuliskan apa yang akan dicari untuk menyelesaikan soal tanpa membuat rencana yang jelas. Jenis kesalahan yang dilakukan SP-1 pada tahap ini adalah kesalahan konsep yaitu tidak menggunakan informasi yang diberikan soal secara menyeluruh untuk membuat rencana penyelesaian. Dari wawancara dengan SP-1 diperoleh petikan sebagai berikut:

\begin{tabular}{|l|l|l|l|}
\hline P1.1.12 & $:$ & $\begin{array}{l}\text { Untuk menjawab pertanyaan pada soal tersebut, apa } \\
\text { rencana yang kamu buat? }\end{array}$ & \\
\hline SP-1.1.12 & $:$ & $\begin{array}{l}\text { Yaitu dengan mengetahui berapa butir kelereng, } \\
\text { persentase dari jumlah keseluruhan mereka bertiga. }\end{array}$ & K \\
\hline P1.1.13 & $:$ & Maksudnya bagaimana? & \\
\hline SP-1.1.13 & $:$ & Gimana ya pak, & \\
\hline P1.1.14 & $:$ & $\begin{array}{l}\text { Kan tadi menyebutkan berapa butir kelereng kan, } \\
\text { kelereng siapa? }\end{array}$ & \\
\hline SP-1.1.14 & $:$ & Ridho pak & \\
\hline P1.1.15 & $:$ & $\begin{array}{l}\text { Bagaimana kamu bisa menentukan banyak kelereng } \\
\text { Ridho? }\end{array}$ & \\
\hline SP-1.1.15 & $:$ & Diam..... & \\
\hline P1.1.16 & $:$ & Yang ditanyakan apa sih? & \\
\hline SP-1.1.16 & $:$ & Persentase kelereng Ridho pak? & PK \\
\hline P1.1.17 & $:$ & $\begin{array}{l}\text { Terus untuk mencari jumlah kelereng Ridho } \\
\text { bagaimana? }\end{array}$ & \\
\hline SP-1.1.17 & $:$ & Tidak tahu pak & \\
\hline
\end{tabular}


Berdasarkan jawaban SP-1 pada tahap membuat rencana penyelesaian dan petikan wawancara dengan label SP-1.1.12 di atas, terdapat kesamaan kesalahan yang dilakukan, yaitu kesalahan konsep, SP-1 hanya menyebutkan apa yang akan dicari tanpa membuat rencana yang jelas. Faktor penyebab terjadinya kesalahan adalah SP-1 tidak mengetahui langkah apa yang harus ditempuh untuk menyelesaikan soal (SP-1.1.17)

3) Langkah melaksanakan rencana penyelesaian

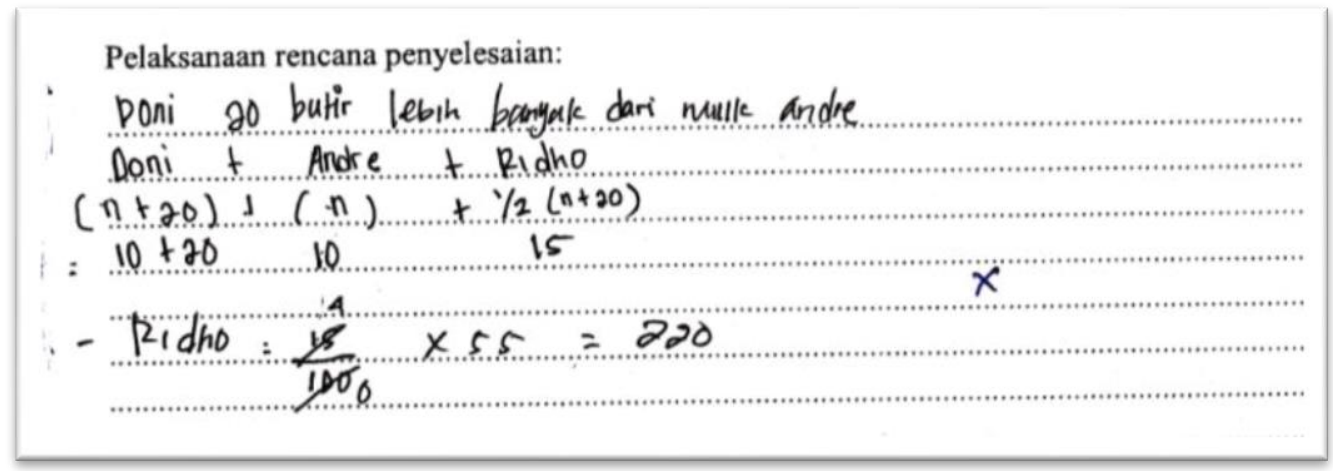

Gambar 3: Jawaban Siswa pada tahap pelaksanaan rencana penyelesaian Pada tahap melaksanakan rencana penyelesaian ini, kesalahan yang dilakukan oleh SP-1 adalah tidak lengkap dalam menuliskan model matematika, termasuk jenis kesalahan fakta dan salah dalam menentukan persentase suatu nilai, termasuk jenis kesalahan prinsip. Dari wawancara diperoleh petikan sebagai berikut:

\begin{tabular}{|c|c|c|c|}
\hline P1.1.18 & & $\begin{array}{l}\text { Sekarang pada tahap pelaksanaan rencana penyelesaian. } \\
\text { Apa yang kamu lakukan pada tahap ini? }\end{array}$ & \\
\hline SP-1.1.18 & & $\begin{array}{l}\text { Saya melakukan ini pak. (sambil menunjuk pada lembar } \\
\text { jawabannya) } \\
\text { Doni } 20 \text { butir lebih banyak dari milik Andre } \\
\text { Doni }+ \text { Andre }+ \text { Ridho } \\
(\mathrm{n}+20)+(\mathrm{n})+1 / 2(\mathrm{n}+20) \\
10+20 \quad 10 \quad 15 \\
\text { Ridho }=\frac{15}{10} \times 55=220\end{array}$ & $\mathbf{F}$ \\
\hline P1.1.19 & & Maksudnya? & \\
\hline SP-1.1.19 & & .............(diam) & \\
\hline P1.1.20 & & Maksudnya apa Doni + Andre + Ridho? & \\
\hline SP-1.1.20 & & $\begin{array}{l}\text { Kan pada soal diketahui jumlah kelereng mereka bertiga } \\
\text { pak }\end{array}$ & \\
\hline P1.1.21 & & $\begin{array}{l}\text { Terus kenapa kok ditulisnya begitu? Coba dilihat lagi } \\
\text { soalnya }\end{array}$ & \\
\hline
\end{tabular}




\begin{tabular}{|c|c|c|c|}
\hline SP-1.1.21 & 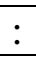 & Jumlah kelereng mereka bertiga 55 butir pak & $\mathbf{P F}$ \\
\hline P1.1.22 & : & Jadi seharusnya ditulis bagaimana? & \\
\hline SP-1.1.22 & & Doni + Andre + Ridho $=55$ & $\mathbf{P F}$ \\
\hline P1.1.23 & & $\begin{array}{l}\text { Oh gitu. Terus }(n+20)+(n)+1 / 2(n+20) \text {, maksudnya } \\
\text { apa? }\end{array}$ & \\
\hline SP-1.1.23 & 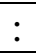 & Itu kurang pak, seharusnya ada sama dengan 55 nya. & $\mathbf{P F}$ \\
\hline P1.1.24 & & Dari mana kamu dapat itu? & \\
\hline SP-1.1.24 & 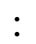 & Kan disoalnya ada kelereng Andre $n$ butir toh pak & \\
\hline P1.1.25 & & Ya benar. Terus $10+20 \quad 10 \quad 15$ maksudnya apa? & \\
\hline SP-1.1.25 & 曈 & Doni $10+20$, Andre 10, Ridho 15 & \\
\hline P1.1.26 & & Dari mana kamu dapatkan itu? & \\
\hline SP-1.1.26 & & $\begin{array}{l}\text { Kan jumlahnya } 55 \text { butir pak. Jadi kalau semuanya } \\
\text { ditotal jadi } 55 \text {. }\end{array}$ & \\
\hline P1.1.27 & & $\begin{array}{l}\text { Maksudnya, untuk mendapatkan } 10+20 \quad 10 \quad 15 \\
\text { itu dari mana? }\end{array}$ & \\
\hline SP-1.1.27 & 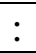 & Dicocok-cocokan pak & \\
\hline P1.1.28 & & $\begin{array}{l}\text { Lho ya ga boleh toh. Masa kok ditebak. Iya kalau } \\
\text { nebaknya langsung benar, kalau tidak, kan lama } \\
\text { ketemunya? }\end{array}$ & \\
\hline SP-1.1.28 & 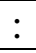 & Iya pak, maaf & \\
\hline $\mathrm{P} 1.1 .29$ & & $\begin{array}{l}\text { Sekarang perhatikan ini (menunjuk pada lembar } \\
\text { jawaban siswa). Kan tadi sudah dituliskan }(n+20)+(n) \\
+1 / 2(n+20)=55\end{array}$ & \\
\hline SP-1.1.29 & & Iya pak & \\
\hline P1.1.30 & & Bentuk apakah itu & \\
\hline SP-1.1.30 & & Aljabar pak & \\
\hline P1.1.30 & & $\begin{array}{l}\text { Lho kan kamu tahu. Pada bentuk aljabar itu terus } \\
\text { diapakan? }\end{array}$ & \\
\hline SP-1.1.31 & & Dicari nilai n pak & \\
\hline $\mathrm{P} 1.1 .32$ & a & Kamu bisa mencari nilai $\mathrm{n}$ nya? & \\
\hline SP-1.1.32 & & Tidak & \\
\hline P1.1.33 & & Kenapa? & \\
\hline SP-1.1.33 & & Sulit pak & \\
\hline P1.1.34 & & $\begin{array}{l}\text { Kan sudah diajari tentang penyelesaian persamaan } \\
\text { aljabar? }\end{array}$ & \\
\hline SP-1.1.34 & & Sudah pak,tapi ga iso (tidak bisa) & \\
\hline P1.1.35 & & $\begin{array}{l}\text { Ya sudah nanti belajar lagi tentang penyelesaian } \\
\text { persamaan aljabar. Sekarang ini Ridho }=\frac{15}{100} \times 55= \\
220 \text {. Maksudnya apa? }\end{array}$ & \\
\hline SP-1.1.35 & & Mencari persen Ridho pak & \\
\hline P1.1.36 & & Yakin seperti itu caranya? & \\
\hline SP-1.1.36 & & Iya pak. Kan kelereng Ridhonya 15 dan total 55 & \\
\hline P1.1.37 & & Kapan dapat pelajaran tentang persen? & \\
\hline SP-1.1.37 & & Waktu MI dan kemarin semester 1 pak & \\
\hline P1.1.38 & & Betul seperti itu cara untuk mencari persentase Ridho? & \\
\hline
\end{tabular}




\begin{tabular}{|l|l|l|l|}
\hline SP-1.1.38 & $:$ & $\begin{array}{l}\text {........(diam) } \\
\text { Salah ya pak? }\end{array}$ & \\
\hline P1.1.39 & $:$ & Iya nak, coba diingat lagi & \\
\hline SP-1.1.39 & $:$ & Ga ingat pak, ingatnya itu & \\
\hline P1.1.40 & $:$ & $\begin{array}{l}\text { Sekarang lihat jawabanmu lagi. Itu kan ada per seratus, } \\
\text { kenapa? }\end{array}$ & \\
\hline SP-1.1.40 & $:$ & Kan mau dijadikan persen pak. Jadi dibagi seratus & PP \\
\hline P1.1.41 & $:$ & $\begin{array}{l}\text { O........ } \\
\text { Seharusnya gini nak, bukan dibagi 100, tapi dibagi } \\
\text { jumlah keseluruhan baru dikalikan 100\% }\end{array}$ & \\
\hline
\end{tabular}

Berdasarkan jawaban SP-1 pada tahap pelaksanaan rencana penyelesaian dan jawaban SP-1 dengan label SP-1.1.18 diketahui bahwa SP-1 melakukan kesalan fakta dengan tidak lengkap dalam menuliskan model matematika dan kesalahan prinsip dengan salah menentukan pesentase suatu nilai. Dari petikan wawancara di atas diperoleh penyebab SP-1 melakukan kesalahan yaitu: (1) kekurangtelitian dalam membaca soal berdasarkan pada jawaban subjek penelitian dengan kode SP-1.1.21, SP-1.1.22, SP-1.1.23 dan SP-1.1.24 (2) kurangnya pemahaman siswa tentang bagaimana menentukan persentase suatu nilai, berdasarkan pada jawaban subjek penelitian dengan kode SP-1.1.40.

4) Langkah memeriksa kembali dan mengambil kesimpulan

Mengecek kembali dan kesimpulan:

Jidi Presenfase fidho $: 270$

Gambar 4: Jawaban Siswa pada tahap memeriksa kembali

Pada tahap memeriksa kembali dan mengambil kesimpulan, SP-1 melakukan kesalahan fakta, yaitu salah dalam membuat kesimpulan dari pertanyaan soal.

Dari wawancara dengan SP-1 diperoleh petikan sebagai berikut:

\begin{tabular}{|l|l|l|l|}
\hline P1.1.41 & $:$ & $\begin{array}{l}\text { Sekarang tahap terakhir yakni mengecek kembali dan } \\
\text { kesimpulan. Apa yang kamu tuliskan? }\end{array}$ & \\
\hline SP-1.1.41 & $:$ & Salah pak. Karena tadi mencari persen nya salah. & F \\
\hline P1.1.42 & $:$ & $\begin{array}{l}\text { Kalau misal tadi mencari persentasenya benar, apakah } \\
\text { kamu yakin akan bisa benar pada langkah ini? }\end{array}$ & \\
\hline SP-1.1.42 & $: \begin{array}{l}\text { Iya pak. Kan tinggal menjawab pertanyaan soal aja. } \\
\text { Ngitungnya sudah. Tapi karena tadi salah, ya salah lagi } \\
\text { di tahap ini. }\end{array}$ & PF \\
\hline
\end{tabular}


Berdasarkan jawaban SP-1 pada tahap mengecek kembali dan membuat kesimpulan dan jawaban subjek penelitian dengan label SP-1.1.41 terdapat kesamaan kesalahan yang dilakukan yaitu salah dalam membuat kesimpulan. Kesalahan ini merupakan jenis kesalahan fakta. Dan faktor penyebab SP-1 melakukan kesalahan adalah kesalahan pada tahap sebelumnya (SP-1.1.41 dan SP-1.1.42)

b. Soal nomor 2

Suatu proyek pembangunan jembatan direncanakan akan selesai dalam waktu 30 hari denan dikerjakan oleh 12 orang pekerja. Setelah pekerjaan berlangsung 10 hari, pekerjaan terhenti selama 5 hari. Jika kemampuan setiap pekerja dianggap sama, berapa pekerja yang harus ditambahkan agar pembangunan jembatan selesai tepat waktu?

Hasil jawaban SP-1 sebagai berikut:

1) Langkah memahami masalah

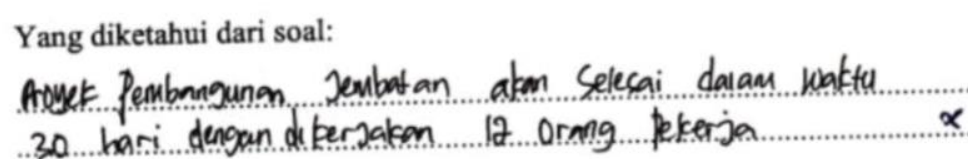

Gambar 5: Jawaban siswa pada tahap memahami masalah soal ke 2

Pada tahap memahami masalah untuk soal somor 2, SP-1 melakukan kesalahan fakta yaitu tidak lengkap dalam menuliskan apa yang diketahui dalam soal.

Dari wawancara dengan SP-1 diperoleh petikan sebagai berikut:

\begin{tabular}{|l|l|l|l|}
\hline $\mathrm{P}$ & $:$ & $\begin{array}{l}\text { Ya sudah belajar lagi ya untuk soal-soal yang serupa. } \\
\text { Sekarang lanjut soal nomor 2. Apakah kamu sudah } \\
\text { membaca dan memahami maksud dari soal nomor 2? }\end{array}$ & \\
\hline
\end{tabular}




\begin{tabular}{|c|c|c|c|}
\hline SP-1.2.1 & : & Sudah pak & \\
\hline $\mathrm{P}$ & : & Paham maksud soal? & \\
\hline SP-1.2.2 & $:$ & Paham pak & \\
\hline $\mathrm{P}$ & : & Apa yang diketahui dalam soal & \\
\hline SP-1.2.3 & : & $\begin{array}{l}\text { Proyek pembangunan jembatan akan selesai dalam } \\
\text { waktu } 30 \text { hari dengan dikerjakan } 12 \text { orang pekerja. }\end{array}$ & $\mathbf{F}$ \\
\hline $\mathrm{P}$ & : & Apakah hanya itu? & \\
\hline SP-1.2.4 & $:$ & $\begin{array}{l}\text { Eh, iya pak. Ada telah bekerja selama } 10 \text { hari kemudian } \\
\text { libur } 5 \text { hari. }\end{array}$ & \\
\hline $\mathrm{P}$ & : & $\begin{array}{l}\text { Lho kan, kenapa kemarin tidak ditulis semuanya secara } \\
\text { lengkap? }\end{array}$ & \\
\hline SP-1.2.5 & $:$ & Tidak tahu pak. Kurang teliti, kesusu (tergesa-gesa) juga & PF \\
\hline $\mathrm{P}$ & : & Selanjutnya apa yang ditanyakan soal? & \\
\hline SP-1.2.6 & $:$ & $\begin{array}{l}\text { Setelah dikerjakan selama } 10 \text { hari, pekerjaan dihentikan } \\
\text { selama } 5 \text { hari. Berapa pekerjaan yang harus } \\
\text { ditambahkan agar pembangunan jembatan selesai tepat } \\
\text { waktu pak }\end{array}$ & \\
\hline $\mathrm{P}$ & : & Pekerjaan yang harus ditambahkan? Benarkah? & \\
\hline SP-1.2.7 & : & $\begin{array}{l}\text { Eh, bukan pekerjaan pak, tapi pekerja, maksudnya } \\
\text { orangnya pak. }\end{array}$ & \\
\hline
\end{tabular}

Berdasarkan jawaban SP-2 pada tahap memahami masalah dan hasil wawancara dengan label SP-1.1.3 terdapat kesamaan kesalahan yang dilakukan yaitu tidak lengkap dalam menuliskan apa yang diketahui dalam soal. Kesalahan yang dilakukan pada tahap ini merupakan kesalahan fakta. Dari petikan wawancara di atas, pada jawaban dengan kode SP-1.2.5 diketahui bahwa faktor penyebab SP-1 melakukan kesalahan adalah kekurangcermatan SP-1 dalam membaca soal dan tergesa-gesa.

2) Langkah merencanakan penyelesaian

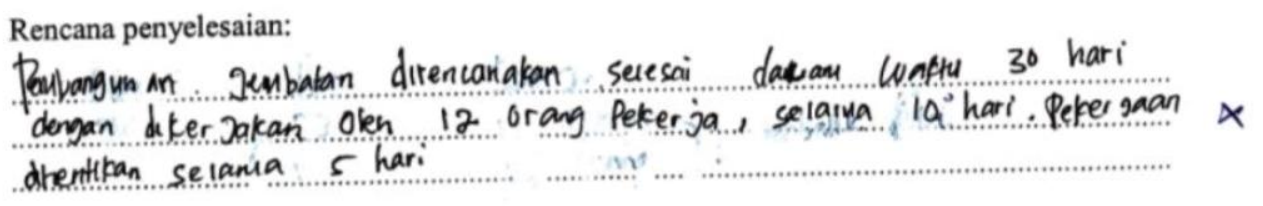

Gambar 6: jawaban siswa pada tahap merencanakan penyelesaian soal nomor 2 Pada tahap merencanakan penyelesaian, SP-1 melakukan kesalahan yaitu tidak membuat perbandingan yang sesuai dengan informasi yang terdapat pada soal. Jenis kesalahan yang dilakukan adalah kesalahan konsep. Dari wawancara diperoleh petikan sebagai berikut: 


\begin{tabular}{|l|l|l|l|}
\hline P & $:$ & $\begin{array}{l}\text { Oke, selanjutnya untuk dapat mendapatkan jawaban atas } \\
\text { pertanyaan itu, bagaimanan tahap rencana penyelesaian } \\
\text { yang kamu lakukan? }\end{array}$ & \\
\hline SP-1.2.8 & $:$ & $\begin{array}{l}\text { Pembangunan jembatan direncanakan selesai dalam } \\
\text { waktu 30 hari dengan dikerjakan oleh 12 orang pekerja, } \\
\text { selama 10 hari pekerjaan dihentikan selama 5 hari }\end{array}$ & \\
\hline P & $:$ & Maksudnya bagaimana? & \\
\hline SP-1.2.9 & $:$ & Tidak tahu pak. Bingung & \\
\hline P & $:$ & $\begin{array}{l}\text { Gini lo nak, tadi kan kamu akan mencari banyak pekerja } \\
\text { yang akan ditambahkan toh. Untuk itu kamu butuh apa? }\end{array}$ & \\
\hline SP-1.2.10 & $:$ & Jumlah pekerja pak. Kemudian nanti dikurangi 12 orang & \\
\hline P & $:$ & Kenapa harus dikurangi 12 orang? & \\
\hline SP-1.2.11 & $:$ & $\begin{array}{l}\text { Karena mula-mula yang bekerja 12 orang pak. Jadi nanti } \\
\text { tambahannya harus dikurangi 12. }\end{array}$ & \\
\hline P & $:$ & $\begin{array}{l}\text { Apakah kamu yakin bahwa nanti pekerja yang } \\
\text { dibutuhkan akan lebih banyak? }\end{array}$ & \\
\hline SP-1.2.12 & $:$ & Ini kan contoh perbandingan berbalik nilai kan pak? & \\
\hline P & $:$ & $\begin{array}{l}\text { Darimana kamu dapat kesimpulan bahwa ini merupakan } \\
\text { contoh perbandingan berbalik nilai. }\end{array}$ & \\
\hline SP-1.2.13 & $:$ & $\begin{array}{l}\text { Lupa-lupa ingat pak. Jadi ini nanti menggunakan } \\
\text { perkalian lurus. }\end{array}$ & \\
\hline P & $:$ & Maksudnya apa dengan perkalian lurus? & \\
\hline SP-1.2.14 & $:$ & Ini lo pak. (menunjuk ada lembar jawaban) & \\
\hline P & $:$ & $\begin{array}{l}\text { o... ya ya... } \\
\text { jadi menurut kamu yang dibandingkan apa? }\end{array}$ & \\
\hline SP-1.2.15 & $:$ & Jumlah pekerja dan hari yang dibutuhkan. & \\
\hline
\end{tabular}

Dari petikan wawancara di atas, pada jawaban dengan kode SP-1.2.9 diperoleh penyebab SP-1 melakukan kesalahan adalah kurangnya kemampuan analisis terhadap informasi-informasi pada soal dan kurangnya pemahaman tentang konsep perbandingan.

3) Langkah pelaksanaan rencana penyelesaian

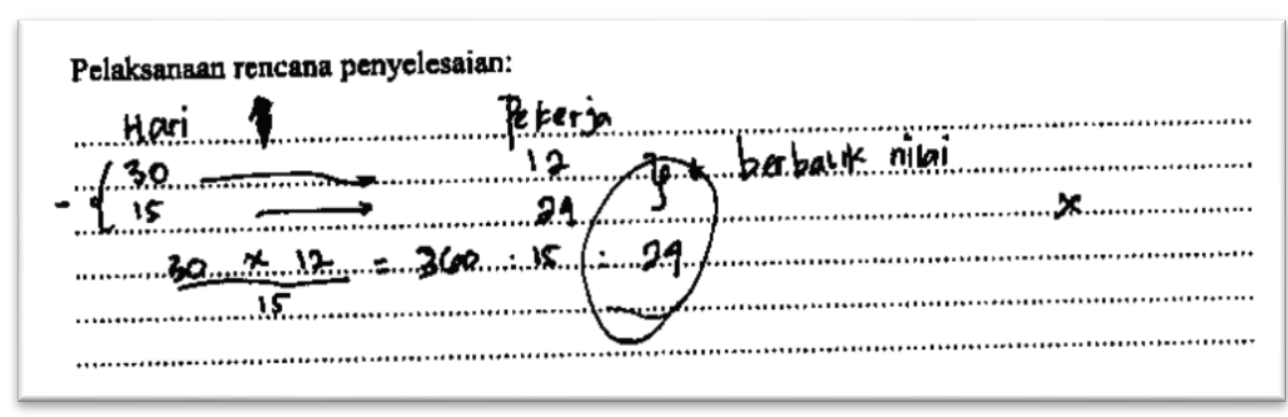


Gambar 6: Jawaban siswa pada tahap pelaksanaan rencana penyelesaian soal nomor 2

Kesalahan yang dilakukan SP-1 pada tahap pelaksanaan rencana penyelesaian adalah kesalahan dalam membentuk perbandingan dengan benar. Kesalahan ini termasuk dalam kesalahan konsep. Dari wawancara dengan SP-1 diperoleh petikan sebagai berikut:

P : Jadi kamu menuliskan itu pada tahap pelaksanaan rencana penyelesaian. Coba jelaskan yang kamu tulis!

SP- $\quad$ : Pekerjaan akan selesai dalam waktu 30 hari jika

1.2.16 diselesaikan oleh 12 pekerja, sehingga supaya pekerjaan selesai dalam waktu 15 hari maka pekerjanya 24 orang. Dari perkalian lurus itu pak. $\frac{30 \times 12}{15}=360: 15=24$

$\mathrm{P} \quad$ : Kq kamu menggunakan perbandingan itu, 30 hari dengan 12 pekerja?

SP- $\quad$ : Dari soal seperti itu pak

P : Terus yang telah dikerjakan selama 10 hari bagaimana? Apakah nanti tidak merubah apa yang dibandingkan?

SP- $\quad$ : Hmmmmm....salah ya pak

1.2 .18

$\mathrm{P}$

SP-

1.2.19

$\mathrm{P}$

SP-

1.2.20

$\mathrm{P}$

SP-

1.2.21

$\mathrm{P}$

SP-

1.2.22

$\mathrm{P}$

SP-

1.2 .23

$\mathrm{P}$

SP-
: Begini nak, semula kan direncanakan 30 hari dan sudah bekerja 10 hari. Sisa harinya bagaimana?

: Tinggal 20

: Berapa pekerja yang harus menyelesaikannya?

: 12

: Jadi perbandingannya bagaimana?

: 20 hari dengan 12 pekerja

: Lha itu benar, kemarin kenapa masih menggunakan 30 hari dengan 12 pekerja?

: Ga kepikiran sampai situ pak

: Sekarang kalau 15 hari asalnya dari mana?

: Kerja 10 hari libur 5 jadi harinya menjadi 30 dikurangi 10 dikurangi 5

: Sekarang coba kamu selesaikan perbandingan baru yang diperoleh tadi

: Yang 20 hari dengan 12 pekerja itu pak 


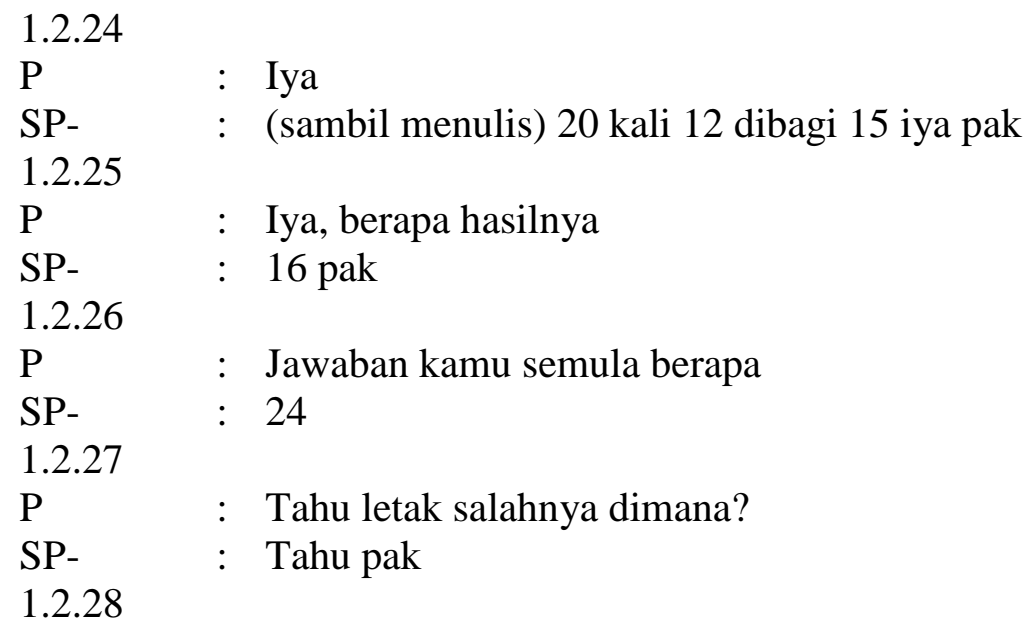

wawancara di atas, pada kode jawaban SP-1.2.16 dan SP-1.2.17 dapat diketahui penyebab SP-1 melakukan kesalahan adalah ketidakcermatan SP-1 dalam menganalisis item-item yang diketahui dalam soal untuk memperoleh perbandingan yang tepat.

4) Langkah mengecek kembali dan kesimpulan

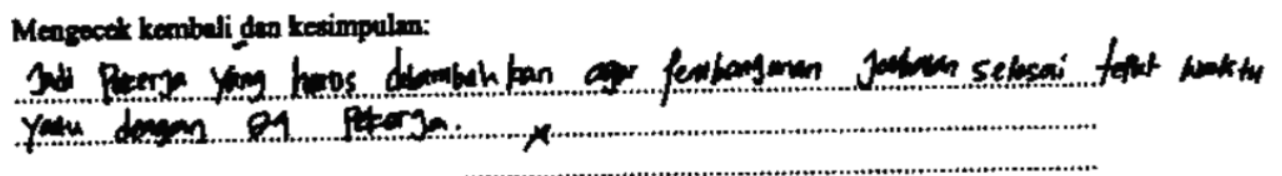

Gambar 8: Jawaban siswa pada tahap mengecek kembali soal nomor 2

Pada tahap mengecek kembali dan kesimpulan, SP-1 melakukan kesalahan

fakta, yaitu SP-1 salah dalam membuat kesimpulan. Dari wawancara diperoleh transkrip sebagai berikut:

$\mathrm{P} \quad$ : Sekarang tahap terakhir mengecek kembali dan kesimpulan. Apa yang kamu tuliskan?

SP- $\quad$ : Jadi pekerja yang harus ditambahkan agar

1.2.29 pembangunan jembatan selesai tepat waktu yaitu dengan 24 pekerja?

$\mathrm{P} \quad$ : Benarkah seperti itu?

SP- : : Salah pak

1.2 .30

$\mathrm{P} \quad$ : Seharusnya berapa?

SP- $\quad: 16$ pak

1.2 .31

$\mathrm{P}$

: Kok 16 coba kamu baca lagi apa yang ditanyakan soal 


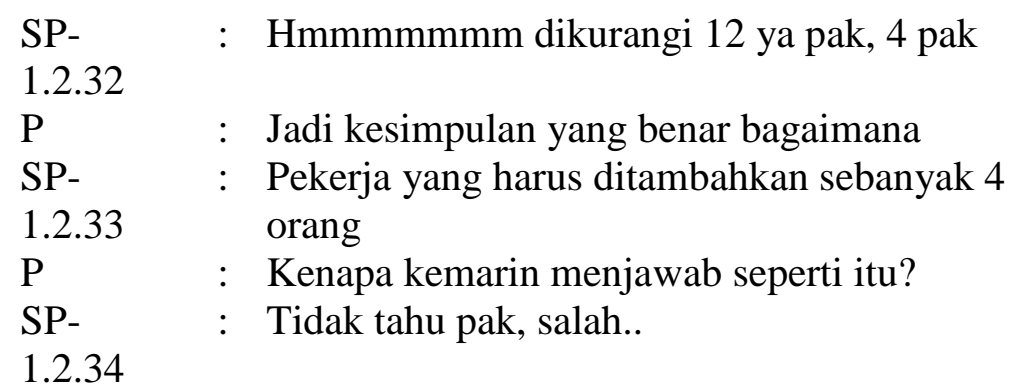

Dari petikan wawancara di atas terdapat kesesuaian jawaban SP-1 dengan hasil wawancara. Kekurangtelitian SP-1 dalam membaca dan memahami soal menjadi penyebab terjadinya kesalahan, selain itu juga dipengaruhi adanya kesalahan pada tahap sebelumnya, ini diketahui dari jawaban subjek penelitian dengan kode SP-1.2.32 dan SP-1.2.33.

\section{Kesimpulan}

Kesalahan yang dilakukan siswa dalam menyelesaikan soal cerita tentang perbandingan terletak pada tahap memahami masalah, membuat rencana penyelesaian, melaksanakan rencana penyelesaian dan pada tahap mengecek kembali dan membuat kesimpulan. Jenis-jenis kesalahan yang dilakukan siswa antara lain 1) kesalahan fakta: tidak lengkap dalam menuliskan apa yang diketahui dalam soal dan membuat kesimpulan, 2) kesalahan konsep: tidak mampu menyusun perbandingan yang benar berdasarkan informasi dari soal, salah dalam menentukan nilai-nilai yang dibandingkan, 3) kesalahan prinsip: salah dalam menentukan persentase suatu nilai. Faktorfaktor yang menyebabkan siswa melakukan kesalahan antara lain kekurangtelitian siswa dalam membaca soal, kurangnya pemahaman siswa tentang konsep persentase, kurangnya kemampuan analisis siswa terhadap informasi yang terdapat dalam soal, ketidakcermatan siswa dalam menganalisis intem-item yang diketahui dalam soal untuk memperoleh perbandingan yang tepat, ketidaktahuan siswa terhadap langkah apa yang harus dilakukan untuk menyelesaikan soal, dan terpengaruh pada jawaban sebelumnya. Untuk mengatasi kesalahan yang serupa terjadi kembali dalam kegiatan pembelajaran, maka model pembelajaran berbasis masalah merupakan salah satu alternatif yang bisa digunakan. Hal ini karena adanya kesesuaian antara faktor penyebab dan karakteristik model pembelajaran. Alternatif dsini meliputi rencana Pelaksanaan Pembelajaran (RPP), Lemba Kerja Siswa (LKS), dan Evaluasi. 


\section{Referensi}

R, Soedjadi. 2000. Kiat Pendidikan Matematika di Indonesia. Jakarta: Direktorat Jenderal Pendidikan Tinggi Departemen Pendidikan Nasional

NCTM. 2000. Principles and Standars for School Mathematics. United State: NCTM, Inc

Yaya, S Kusumah. 2011. Literasi Matematis: Pengembangan Pembelajaran MIPA berrientasi Softskill. in Seminar Nasional Pendidikan MIPA, Lampung, p. 6.

S J, Lamon. 1993. Ratio and Proportion: Coneccting Content and Children's Thinking. Journal for Research in Mathematics Educations Vol. 24 No.1 (January), pp. 41-61

Tatag Yuli, Eko Siswono. 2008. Model Pembelajaran Matematika Berbasis Pengajuan dan Pemencahan Masalah untuk Meningkatkan Kemampuan Berpikir Kreatif. Surabaya: Unesa University Press

Stephen Krulik, Jesse A Rudnick. 1995. The New Sourcebook for Teaching Reasoning and Problem Solving in Elementary School. Boston: Allyn and Bacon

S Sahriah, M Muksar, T E Lestari. 2012. Jurnal Online. [Online]. http://jurnalonline.um.ac.id/data/artikel/artikel19EEC8FEB3F87AC825C375098E45CB6 89.pdf

Pratana Phonapichat. 2013. An Analysis of Elementary School Students Difficulties In Mathematical problem Solving. Bangkok: Chulalongkorn University

J K Misailidou and J Barker. 2003. Children's Arguments in Discussion of a "Difficult" Ratio problem: The Role of a Pictorial Representation. 3rd Conference of The European Society for Research in Mathematics Education (CERME3)

G Polya. 1973. How to solve it. New Jersey: Pricenton University Press

G L Musser and W L Burger. 1994. Mathematics For Elementary Teachers a Contemporary Aproach (3 th edition). New Jersey: Printice-Hall

Tarzimah Tambychik. 2010. Student's Difficulties in Mathematics Problem-Solving: What Do They Say? Malaysia: University Kebangsaan Malaysia

L S Cox. 1975. Systematic Errors In The Four Particle Algorithm In Normal and Handicapped Pupulation. Journal for Research in Mathematics Education Rachmadi Widdiharto. 2008. Diagnosis Kesulitan Belajar Siswa Matematika SMP Dan Alternatif Proses Remidinya. Yogjakarta: PPPPTK Matematika 